\title{
Last Thoughts on Campus Planning by Georges Candilis: Bu Ali Sina University (1973-1978)
}

Débora Domingo Calabuig ${ }^{1}$ | Catherine Blain ${ }^{2}$

Received: 2021-03-30 | Final version: 2021-06-12

Abstract

A varied sample of campuses projects can be found in George Candilis' prolific work. The most wellknown are the Freie Universität Berlin and the Faculté de la littérature in Toulouse-Le Mirail by the Candilis-Josic-Woods firm but others were developed later by Candilis with several collaborators. Bu Ali Sina University in the Iranian city of Hamadan was his last opportunity to conceive a complete university from scratch. Between 1973 and 1978, Candilis and the Mandala Collaborative -a local firm founded by Nader Ardalan - jointly carried out the Master Plan and a first version of the campus project. In 1977, and due to a location's change, a second version was planned and some of the facilities were finally built. At that time, the design was discreetly published in architectural magazines and recently the built set was included in a thesis on Ardalan's work. Nevertheless, the campus has not been studied in-depth. This article takes as primary sources the documents available in the Candilis archives and focuses on the design process of the campus to reconstruct its narrative and stages. The objective is to revisit the Bu Ali Sina University, under the assumption that this endpoint of Candilis' thinking is a condensation of a whole practice. This design is the confirmation of a particular way of understanding the university -open to the exchange of knowledge and as a tool for social progress -, which is shaped according to the modernity precepts while preserving its local identity.

Keywords: New universities; university architecture; spaces for higher education

Citation

\section{Últimas reflexiones de Georges Candilis sobre la planificación de campus: Universidad Bu Ali Sina (1973-1978)}

Resumen

\begin{abstract}
El prolífico trabajo de George Candilis incluye una variada muestra de proyectos de campus universitarios. Los más conocidos son la Universidad Libre de Berlín y la universidad de Toulouse-Le Mirail de la firma Candilis-Josic-Woods, pero otros fueron desarrollados posteriormente por Candilis con diversos colaboradores. La Universidad Bu Ali Sina en la ciudad iraní de Hamadan fue su última oportunidad para concebir una nueva universidad. Entre 1973 y 1978, Candilis y Mandala Collaborative - una firma local fundada por Nader Ardalan- llevaron a cabo conjuntamente el Máster Plan y una primera versión del proyecto. En 1977, y debido a un cambio de ubicación, se planificó una segunda versión y finalmente se construyeron algunas de las edificaciones. En ese momento, el proyecto se publicó discretamente en revistas de arquitectura y recientemente el conjunto construido ha sido recogido en una tesis sobre la obra de Ardalan. Sin embargo, el campus no se ha estudiado en profundidad. Este artículo toma como fuentes primarias los documentos disponibles en los archivos de Candilis y se centra en el proceso de diseño del campus para reconstruir su narrativa y escenarios. El objetivo es volver a visitar la Universidad Bu Ali Sina, asumiendo que este punto final del pensamiento de Candilis es una condensación de toda una práctica. El resultado es la confirmación de una forma particular de entender la universidad - abierta al intercambio de conocimientos y como herramienta de progreso social-, que se configura según los preceptos de la modernidad conservando su identidad local.
\end{abstract}

Palabras clave: Nuevas universidades; arquitectura universitaria; espacios para la educación superior

1 Architect, Ph.D., Universitat Politècnica de València, Spain. (ORCiD: 0000-0001-6020-3414; WoS ResearcherID: E-8381-2013) ${ }^{2}$ Architect, Ph.D., E École Nationale Supérieure d'Architecture et de Paysage de Lille, France (ORCiD: 0000-0003-0919-9557). Contact e-mail: dedoca@pra.upv.es 


\section{Introduction}

"Practice makes perfect" seems to be Georges Candilis' motto when dealing with the two architectural programs fundamentally developed throughout his long career: collective housing and spaces for higher education. In the first case, his typological studies clearly evolved from the residential architecture he learned at the hands of Le Corbusier: he built more than 5,000 residential units if we consider the works in Atelier des Bâtisseurs (1951-1955) and those he signed with Alexis Josic and Shadrach Woods (1955-1963) (Joedicke, 1978; Chaljub, 2010). In the second one, it can be affirmed that from 1962 Candilis always had some university project on his drawing board. Bochum, Berlin, Dublin, Toulouse, Zürich, Madrid, Brussels, Latakia, Baghdad, Yarmouk and finally Hamadan, are the destinations of the proposals he designed over a period of 15 years together with various co-authors and collaborators, pursuing an ideal based on "the etymological meaning of the word 'university' which refers to the many different disciplines as to a whole" (Candilis et al., 1964, p. 378) (Figure 1).

Trained at the Polytechnic School of Athens (1931-1936), Candilis came to France in 1945 to work with Le Corbusier and Atelier des Bâtisseurs and achieved great visibility through his active participation in the Congrès internationaux d'architecture moderne (CIAM) and the Team 10 (Blain, 2003; Risselada \& Heuvel, 2005; Pedret, 2013). In the early 1960's, while he had been involved in the French Reconstruction with numerous projects designed in his own office in Paris (created 1955 with Alexis Josic and Shadrach Woods), he was first invited to teach in one of the external ateliers of the Parisian Beaux-Arts school (1963) and was finally associated in the creation of a new one (atelier C, in 1965) that will become one of the new Unité Pédagogique d'Architecture after 1968. Candilis remained involved in that school for a while, but his reflections went beyond this teaching sphere, favouring discussions that would fuel professional practice and vice versa. Throughout his career, he returned several times to a narrative about the origin of the university that would allow him to support his arguments: "In Greece, near a river, under the shade of trees, someone started to speak. Passers-by stopped to listen to him. Subsequently, there were opponents, critics, listeners could choose and make a personal opinion. Thus, was born the University, the Academy of Plato. ... The University is a place without end or beginning where the conditions are favourable to learn, to teach, to seek" (Candilis, 1968, p. 57; Candilis, 2012, p. 235). ${ }^{1}$

One of Candilis' main ambitions was materializing the university campus as a physical foundation open to the free exchange of knowledge, and Candilis achieved it through continuous and flexible designs that characterized the moment. The universities he designed during the 1960s and 1970s especially the paradigmatic Freie Universität Berlin (1963, 1965-1973) - disseminated through the numerous architecture magazines, had great influence in other countries (Domingo-Calabuig et al., 2012).

After the end of his association with Josic and Woods in 1969, Candilis, while working alone on several commissions in France, started a professional activity in the Middle East. Between 1970 and 1978 he was involved in numerous planning and residential projects in Iran, Kuwait, Saudi Arabia, Qatar, the Arab Emirates and Iraq, but also sought to give continuity to his research into universities - as noted in the brochure Kuwait University, showing the expertise of the French international public firm Société Centrale pour l'équipement du territoire-coopération (SCET-COOP) in that specific field of projects (SCET-COOP, n.d.).

Bu Ali Sina University (BASU) in Hamadan, Iran, was the last institution designed by Candilis. ${ }^{2}$ It was planned and carried out by local architect firm, The Mandala Collaborative, created in 1972 by Nader

\footnotetext{
${ }^{1}$ The authors translated all French texts.

${ }^{2}$ Also written as Bou Ali Sinan, Bou Ali Sina and currently Buali Sina University.
} 
Ardalan. ${ }^{3}$ Between 1973 and 1978, Candilis and Ardalan jointly completed the Master Plan and a first version of the campus project. In 1977, there was a change of location and consequently a new campus design took place, some of the academic buildings were finally built.

Figure 1. Map and chronology of the universities designed and/or realized by Georges Candilis

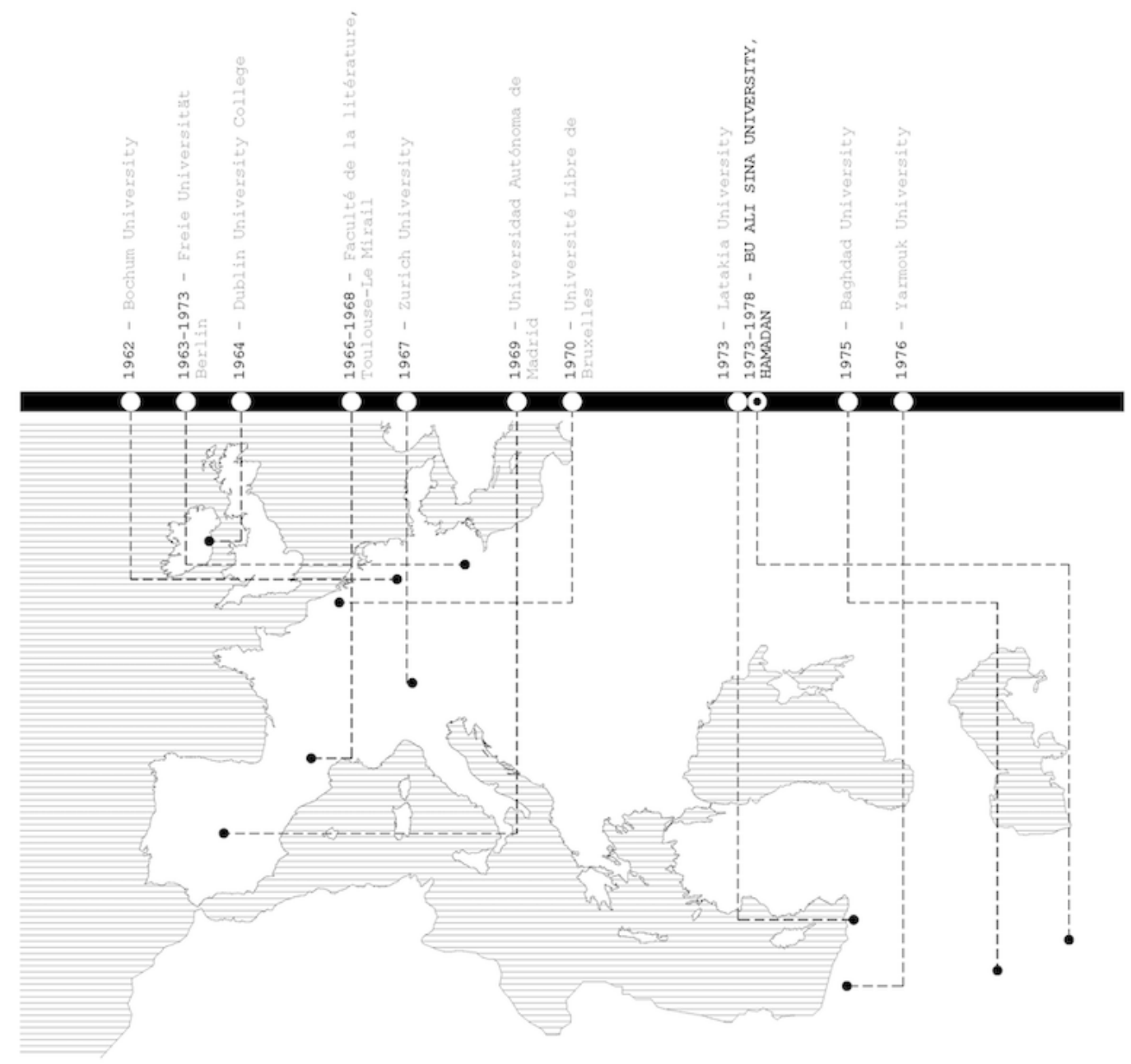

Source: Drawing by the authors.

BASU has recently been studied as part of the professional work of the Iranian architect Nader Ardalan (Aghaei Rad, 2015) and is mentioned in panoramic works of twentieth century architecture history (Emanuel, 1980; Sennott, 2014). At the time, the design was discreetly published, with surprisingly similar information, in magazines such as L'architecture d'Aujourd'hui (Candilis, 1978a), Spacio e Società (Candilis, 1978b), Deutsche Bauzeitung (Candilis, 1978c), and Architecture in Greece (Candilis, 1980). However, this text sets out to a review BASU as a continuity of his university designs, under the assumption that this end point of the journey is a condensation of a whole practice aimed at the perfection of knowledge. It is about delving into this last design exercise, not so much by comparing previous universities, but by launching the hypothesis that BASU is the confirmation of a particular 3 The Mandala Collaborative was based in Tehran (1972-1979) and had an international component: Mandala International,
Boston (MA) that became in 1978 Nader Ardalan Associates office (1978-1983).

ACE, 16 (47) CC BY-ND 3.0 ES | UPC Barcelona, España | Last Thoughts on Campus Planning by Georges Candilis: 
way of understanding the university. - open to the exchange of knowledge and as a tool for social progress -, which is shaped according to the precepts of modernity while preserving its cultural identity.

\section{Modern Universities of the 1960 s and Campus Planning of Candilis-Josic- Woods}

As a consequence of progressive economic growth and investment in social policies that marked the way to the welfare state, a great expansion of universities took place in Western European countries in the early 1960s and throughout the 1970s. Higher education, as in the case of accommodation or leisure, became a matter of "great number", and universities experienced a strong boom, mainly due to two factors: the exponential number of students and the admission policies that up to that point were considered elitist (Coulson et al., 2015). New institutions were created in countries like England, France, Italy, Germany or Spain, and each one shows its peculiarities with respect to its history and traditions (campus, collegiate system, residence...), but all shared a confident and energetic vision about the joint reformulation of the physical university model and its pedagogical system (Castellanos-Gómez et al., 2011). At that time, some studies on campus design were aimed at observing the relationship between urban planning and academic activity (Bullock, Dickens and Steadman, 1968, pp. 299-308), others wanted to optimize the architecture that would house spaces for learning in order to strengthen relationships among the community members (Jockush \& Dunkl, 1974).

Economic growth also made possible the birth of universities in many other countries where the Anglo-Saxon campus model was often exported (Muthesius, 2000). In Africa and the Middle East new opportunities were opened up for local and European architects (METU campus competition, Ankara, 1961; University of Punjab, Lahore, 1962; University of Zambia, Lusaka, 1965) that fed the debates about the campus-city relationship, the housing integration in the campus, or the design mechanisms that would allow future expansions (De Carlo, 1968).

The firm of Candilis-Josic-Woods had a determining role in defining new university campuses, and Shadrach Woods - the most theoretical of the group - found in these programs a good subject for the implementation of his structuralist concepts of "Stem" (1960) and "Web" (1962). The stem concept refers to the linear infrastructure that allows the growth, addition and change of architectural and/or urban cells on each side; the web concept is reached when this stem system is generated in two directions and understood as open, flexible and uniform. The competition's proposal for the Bochum University (Germany, 1962) was the first campus designed by Candilis-Josic-Woods and its compositional fabric is assigned to the stem. Only a year later, together with Manfred Schiedhelm, they won the competition for the Freie Universität Berlin (Germany, 1963), a paradigmatic example of the web principle that was used to coin the term mat-building (Smithson, 1974, p. 573-590). From that moment on, various campus proposals by the team followed; in 1964, they took part in the Dublin University College competition (Ireland), in 1966 the Faculté de léttres was commissioned as an addition to the Toulouse-Le Mirail new town (France), and lastly, they submitted a proposal to the Zurich university competition (Switzerland, 1967). Already the firm had already disbanded when Candilis associated with the Spanish architects Antonio and José Antonio Camuñas and were awarded the second prize of the Universidad Autónoma de Madrid competition (Spain, 1969). Shortly after, he submitted an individual proposal for the Université Libre de Bruxelles (Belgium, 1970) (Woods also submitted his own). During his last activity stage in the Middle East, Candilis participated in the Latakia University competition (Syria, 1973), and designed proposals for the Baghdad University (Iraq, 1975) and the Yarmouk University (Jordan, 1976). The BASU commission began in 1973, but its development

ACE, 16 (47) CC BY-ND 3.0 ES | UPC Barcelona, España | Last Thoughts on Campus Planning by Georges Candilis: Bu Ali Sina University (1973-1978). DOI: http://dx.doi.org/10.5821/ace.16.47.10455 


\section{ACE Architecture, City and Environment}

continued until 1979 and was the last chance for Candilis to elaborate a complete proposal and bring it to execution (Figure 2).

Figure 2. Main design strategies of universities designed by Georges Candilis (\& co-authors)
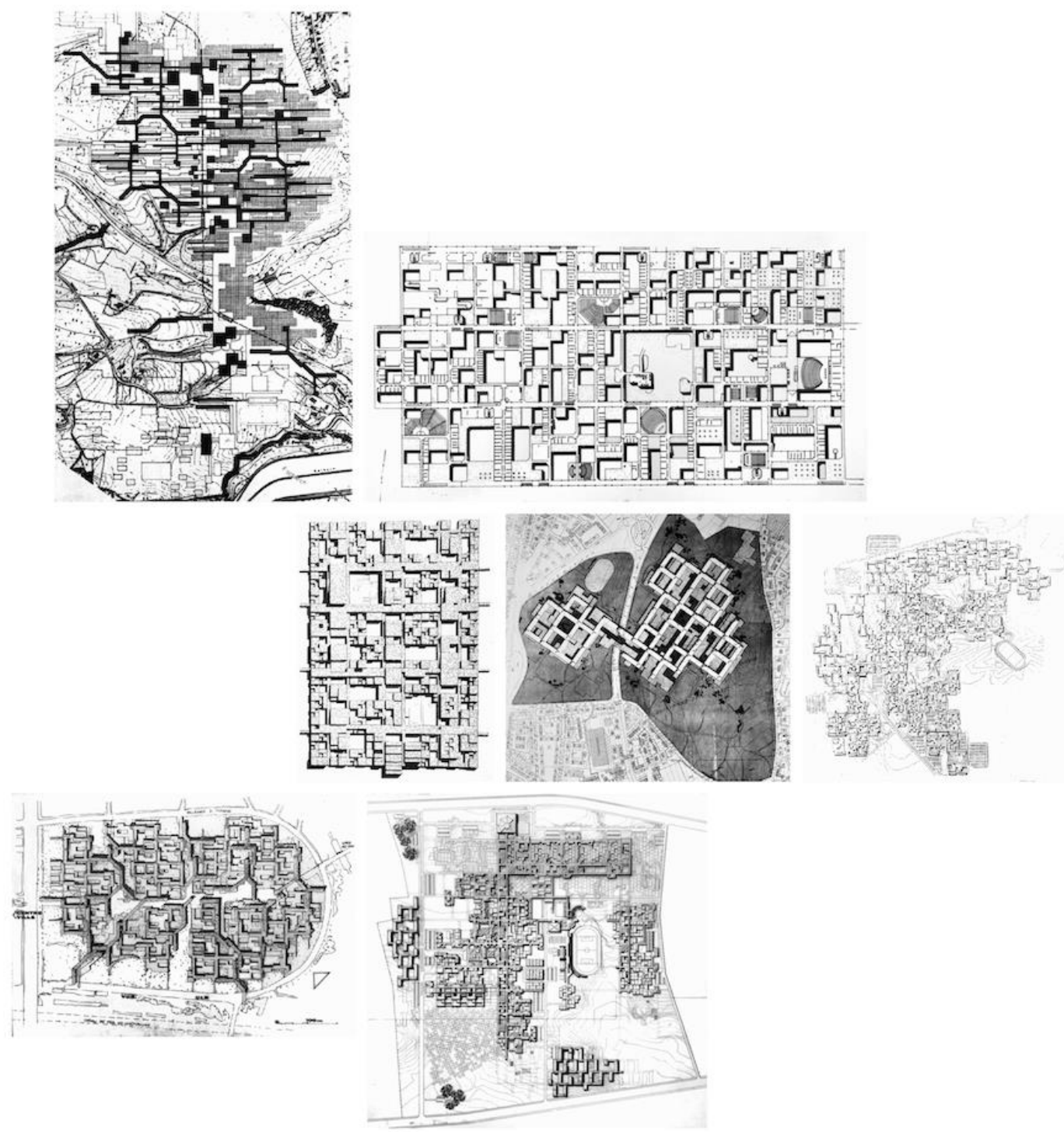

Source: Collage by the authors. Note: From top left to bottom right: Bochum University, Freie Universität Berlin, Faculté de la litérature of Toulouse-Le Mirail, Zurich University, Universidad Autónoma de Madrid, Université Libre de Bruxelles, and Latakia University

\section{BASU within the Educational Modernization of Iran}

In the 1960s, while the Organization of Petroleum-Exporting Countries (OPEC) treatise (signed in Baghdad September 14, 1960) had stabilized the international oil market, the monarchical regime of Mohammad Reza Shah Pahlavi launched an improvement process of the country's infrastructures, including education facilities. State plans for educational expansion allowed an emerging secularized middle class to access university. The equality between men and women in new teaching centres 
responded to a carefully controlled image of the country and to a gradual imposition of Western standards, rather than to free choice (Tehranian, 1993).

The oldest Iranian university is that of Tehran (founded in 1934). New and modern universities were created after the Second World War, most of them influenced by the North American model of higher education and built with the support of the United States. The subsequent ones were: University of Shiraz (founded as Pahlavi University in 1946), University of Isfahan (1946), University of Tabriz (founded as University of Azarabadeghan in 1947), Ferdowsi University of Mashhad (1949), University of Ahvaz (1955), and Sharif University of Technology (founded as Aryamehr Industrial University in 1965) (Tehranian, 1993).

The project of a new public university in Hamadan was launched on February 26, 1973, on the basis of an agreement signed between the Imperial Government of Iran and the French Government, in order to "strengthen their cooperation in the scientific and technical fields at university level" (Décret n. 74-889, 1974). The main functions of this Higher Education and Scientific Research institution are: "a) Training of the specialists needed for development rural and regional development of Iran as well as research related to this development; b) The training of high-level scientific specialists, both in the field of education and in the field of research, in particular to meet the needs of the Iranian educational system."

Hamadan is one of the oldest settlements in Iran and had a population of 100,000 in the 1970s. Located $360 \mathrm{~km}$ from Tehran, in the northwest of the country and in the heart of a mountainous enclave, it was part of the Silk Road. The region has always been the center of the crossroads of East/West caravan routes. With a cold and humid climate, the original urban layout of the city grew around the bazaar, a conglomeration of streets and high-density vaulted passages. The radial morphology (central square in which six avenues converge) is due to the intervention of German architects and urban planners in early 1930 in order to introduce vehicle traffic (Figure 3). The new university in Hamadan will be named after the Persian philosopher and scientist of the 11th century, Avicenna (also Ibn Sīnā or Abu Ali Sina) whose mausoleum is located in the city. The objective is strategic: Hamadan was to become a university city for 5,000 students.

Figure 3. City Plan of Hamadan in the 1970s showing both locations for the BASU campus

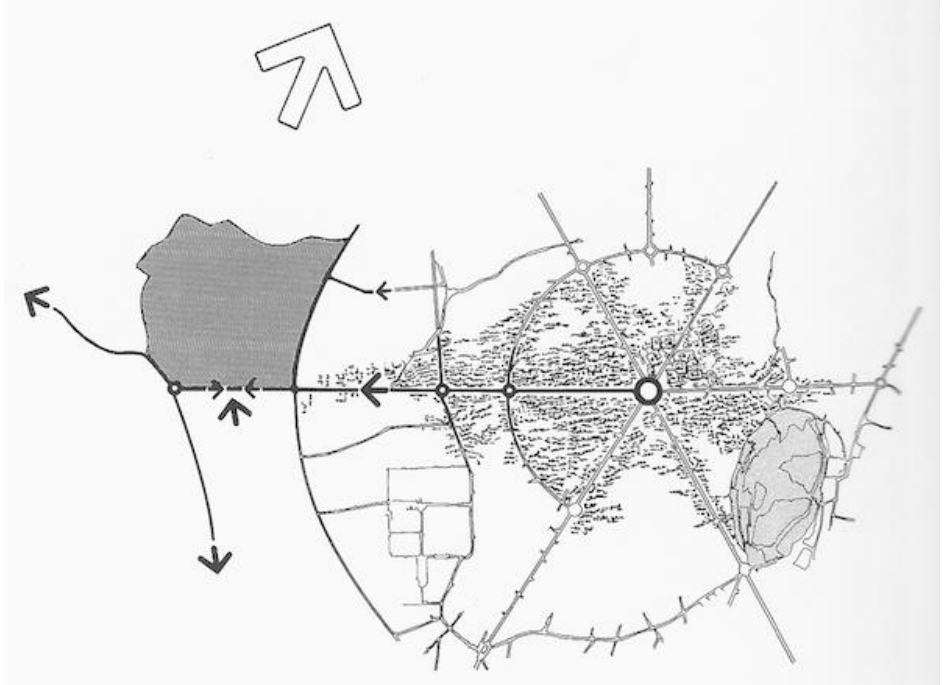

Source: Strukturalismus in Architektur und Städtebau, Lüchinger 1981. Note: On the right in light grey, the first location on the hill; on the left in dark grey, the second and final location.

ACE, 16 (47) CC BY-ND 3.0 ES | UPC Barcelona, España | Last Thoughts on Campus Planning by Georges Candilis: Bu Ali Sina University (1973-1978). DOI: http://dx.doi.org/10.5821/ace.16.47.10455 
On May 7, 1973, the work was entrusted to an association between French architect Georges Candilis and the Mandala Collaborative, an Iranian architects' firm directed by Nader Ardalan. ${ }^{4}$ Trained in the USA (Bachelor of Architecture, Carnegie-Mellon University 1961, Master in Architecture, Harvard 1962), Ardalan who, for two years worked with Skidmore, Owings and Merrill (San Francisco, 1962-1964), came back to Iran in 1964 to become Head of Architectural and Engineering Section of the National Iranian Oil Company, Masjid-i-Sulaiman. From 1966 to 1972 he was Design Partner at the Abdul Aziz Farman Farmaian \& Associates firm in Tehran. The large-scale commission for Hamadan University gave him the opportunity to create his own firm, inviting international collaborators. The association with Georges Candilis, given his experience with the universities of Toulouse and Berlin, that they visited together, seem to have benefited Ardalan (Haeri, 1991). The commitment of each party was not defined by a contract. As suggested by Candilis himself, he should be considered as the author of the conceptual principles: "Although the architects worked as a team without any precise division of tasks, the role of Georges Candilis focused on the design, the role of the Iranians on the final project and the realization" (Candilis, 1978d).

However, other research - focused on the built buildings - concludes the French architect's lack of involvement in the design and appeal to his role of convenience as a foreign partner that would enrich the work (Aghaei Rad, 2015). Nevertheless, for both architects, BASU in Hamadan will be the first and only collaborative experience.

\section{Master Plan and First Campus Planning}

The BASU project was extensive. From September of 1973 to March of 1976, diverse documents were delivered that gradually progressed in the development of the Master Plan and led to the first design of the campus. ${ }^{5}$ In fact, the Master Plan is understood as a process whose third phase becomes the physical definition of the university (Figure 4).

Figure 4. Concept Diagram. The Master Plan Process. Bou Ali Sina University, Hamadan

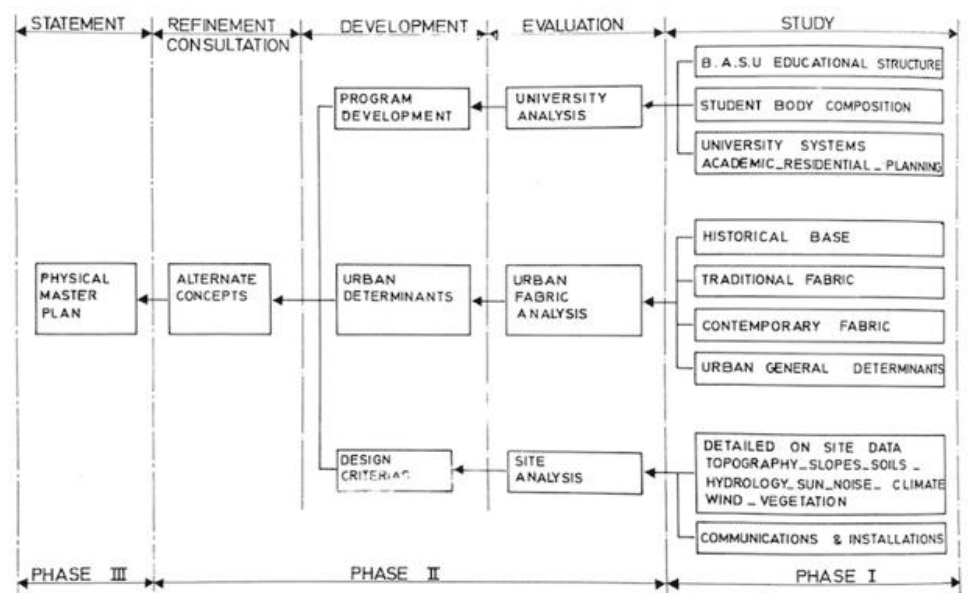

Source: IFA 322 01. Candilis Archives. Cité de l'architecture et du patrimoine. Note: Master Plan BASU Report One, September 1973.

\footnotetext{
${ }^{4}$ Although the contract was not formalized until September 11, the architects had already started to elaborate the Master Plan.

${ }^{5}$ In the Candilis archives of the Cité de l'architecture et du patrimoine (IFA 322 01) there are four bound documents: the Master Plan Report One (September 1973), an Intermediate Report (November 1973), a following volume on University Residence Analyzes (October 1974), and finally the Master Plan Report Phase Three (March 1976) that includes the design of the campus.
}

ACE, 16 (4.7) CC BY-ND 3.0 ES | UPC Barcelona, España | Last Thoughts on Campus Planning by Georges Candilis: Bu Ali Sina University (1973-1978). DOI: http://dx.doi.org/10.5821/ace.16.47.10455 
As a consequence, the Master Plan's first proactive step was to imagine the four years academic program. All the students would share some basic education during the first year and a half, could later opt for the development or the education cluster, and during the last two years would be trained in one of the proposed degrees. All this according to a four terms calendar, alternating two long ones (100 days) for theoretical contents with two short ones (50 days) for fieldwork.

This structure resembled that of a tree and was represented according to the phasing of the Academic program, the space allocation concept, the phasing of building construction and its possibilities of growth (Figure 5).

Figure 5. From top to bottom: 'Concept. Phasing of Academic Program', 'Space Type. Space Allocation Concept', 'Phasing of Building Construction. Growth and Change'

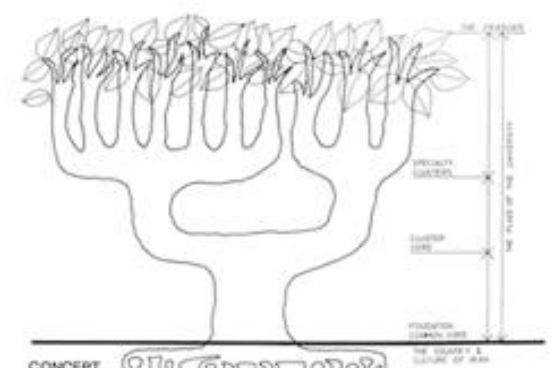

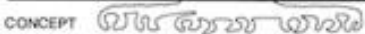
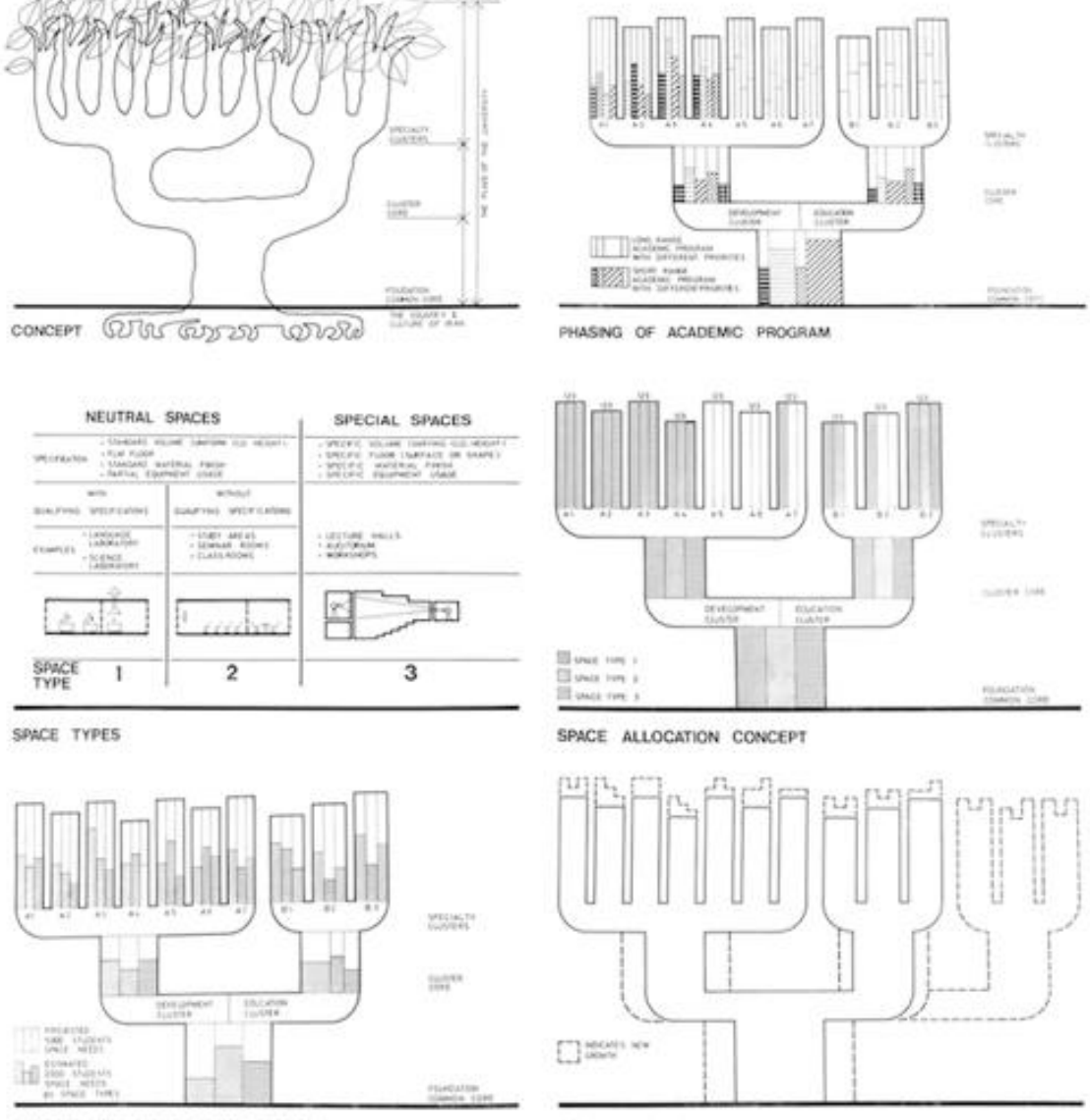

PHASA OF BULDNG COASTRUCTON

CNOWTH \& CHANCE

Source: IFA 322 01. Candilis Archives. Cité de l'architecture et du patrimoine.

Note: Master Plan BASU Report One, September 1973.

In fact, the academic structure was the subject of a detailed study of both the training activities calendar and the organization of the learning spaces that was included in an Intermediary Report prepared by Candilis' office in November 1973. This document ended with a preliminary approach to a relevant programme of required building areas. The final spatial layout schemes closely resembled the definitive academic complex proposal (Figure 6).

ACE, 16 (47) CC BY-ND 3.0 ES | UPC Barcelona, España | Last Thoughts on Campus Planning by Georges Candilis: 
Figure 6. Completion of the Basic Spatial Organisation
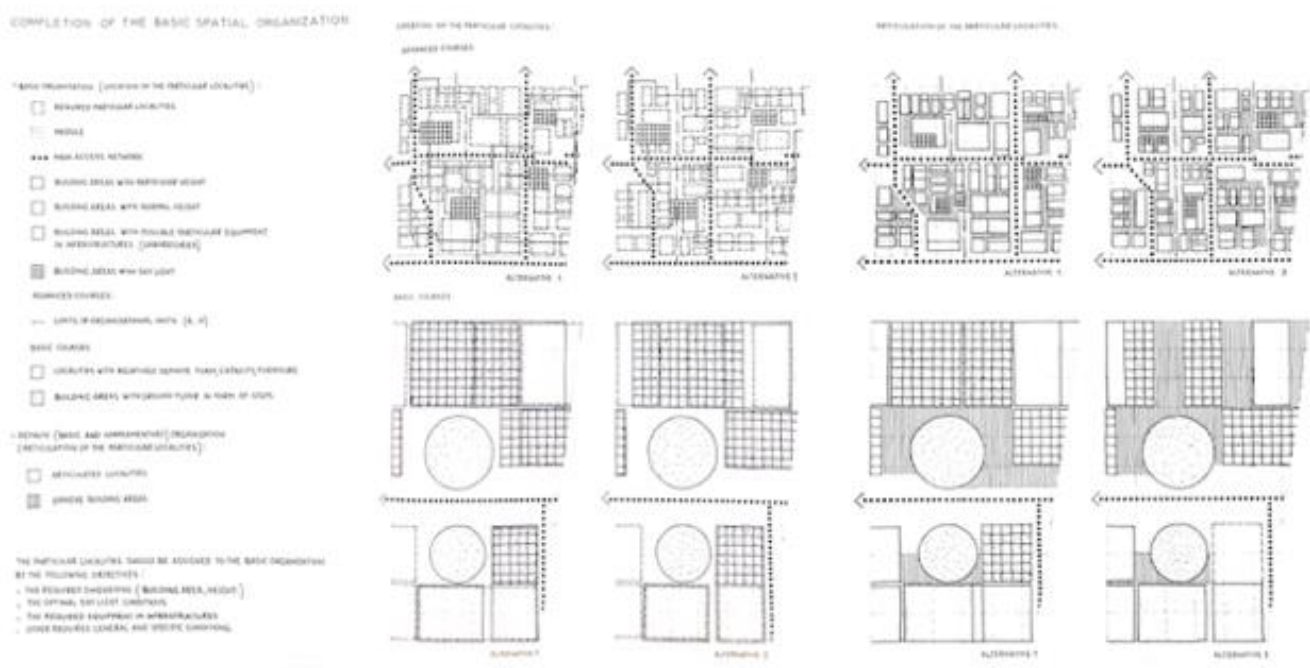

Source: IFA 322 01. Candilis Archives. Cité de l'architecture et du patrimoine.

Note: BASU Intermediary Report, November 1973

The students housing is addressed in another volume dated October $1974 .{ }^{6}$ The functional needs (furniture, area, noise, views, ventilation, light...) are analysed exhaustively for each one of the spaces (sleep, study, lounge, services), and a housing proposal is established, supported by a comparison to student housing study cases from American and Canadian universities including quotes and excerpts from Richard P. Dober publications. The proposal considers accommodating students in different locations depending on the academic program. Thus, the first-year students will stay on the university campus; those of the second cycle will be located in the bazaar and a new residence plan project is sketched; the degree students are distributed among three points of the urban fabric, further away from the campus (Mandala Collaborative \& Candilis, 1974).

The last Master Plan document, identified as Phase /II and dated March 1976, summarized the previous analytical arguments and presented the campus design comprising an academic complex, residential units and sport areas (Figure 7). The section called Relevance insisted on the use of the traditional Iranian architectural forms, with clear allusions to the these by Ardalan and Bakhtiar: "The architectural conception, therefore, of Bu Ali Sina University derives from harmonies of geometric relationships long understood in Iranian history. While it is acknowledged that constituent parts may require different ordering systems, the striving is towards designing these as patterns, each with its own personal order and geometry, which relates in a total sense to the whole. The resulting new level of order becomes a multi-level pattern evoking a sense of unity which not only creates a totally uniform pattern but also gives an order of priority to the constituent elements as is evident in a typical multi-level patterned carpet" (Mandala Collaborative \& Candilis, 1976, p. 8).

The exact layout of the set followed a general underlying pattern of square modules, which respond to the natural geometry of the hill. The local climatic conditions were constantly recalled to justify the definition of spaces. The entire morphology was defined as a system of linear organization to which are added centripetal sub-systems: a main north-south spine would organize the University's smallest units and would house a hierarchy of places with coordinated spatial relationships (Figure $8)$.

\footnotetext{
${ }^{6}$ It seems to have been developed in Iran since the date appears in Persian (Mehr, 21 1352) and the layout does not match the rest of the documents from the Candilis' office.
}

ACE, 16 (47) CC BY-ND 3.0 ES | UPC Barcelona, España | Last Thoughts on Campus Planning by Georges Candilis: 


\section{ACE Architecture, City and Environment}

E-ISSN $1886-4805$

Figure 7. BASU First campus design. Model

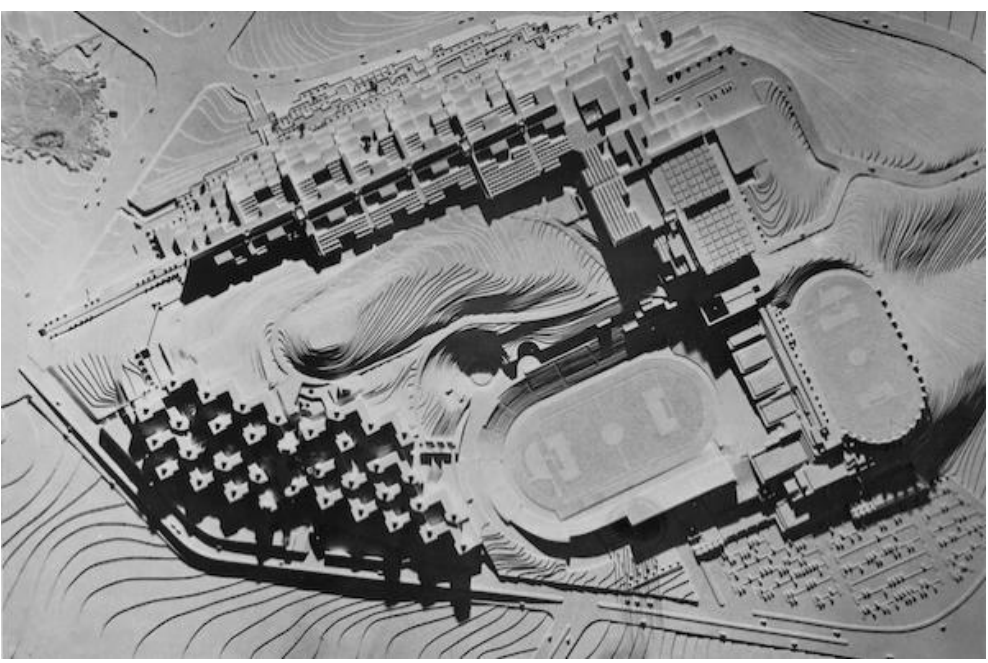

Source: IFA 322 01. Candilis Archives. Cité de l'architecture et du patrimoine. Note: Master Plan BASU Report Three, March 1976

Figure 8. Natural Geometry

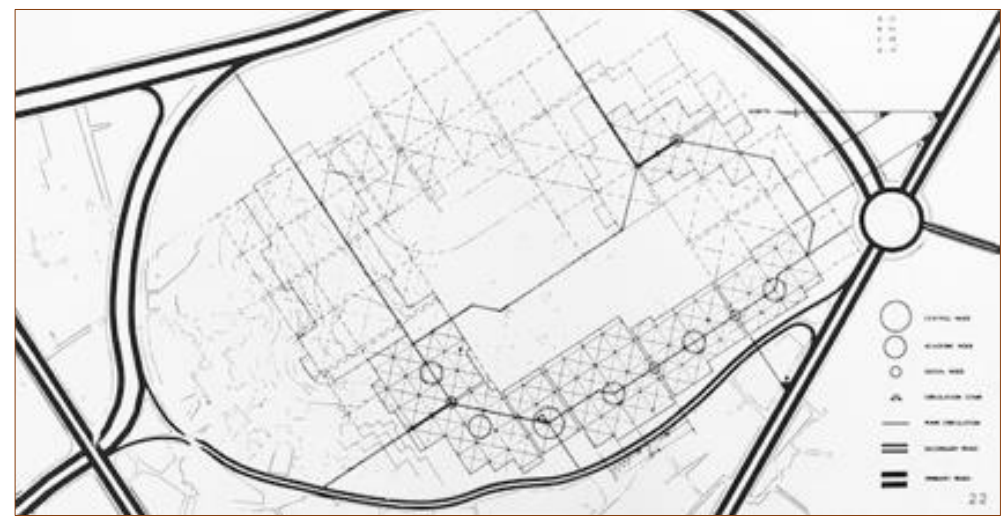

Source: IFA 322 01. Candilis Archives. Cité de l'architecture et du patrimoine.

Note: Master Plan BASU Report Three, March 1976

Finally, the academic complex should be understood as a linear concatenation of spaces on two levels: a lower level with large capacity auditoriums, gymnasium, library, catering..., and a higher one with classes and laboratories. In addition, a service level was added, underlying the entire building, related to mechanical services, kitchen, storage and parking garage. The units' composition generated nodes or crossing places that were formally identified with elements of traditional Iranian architecture: "The chahar sou or covered crossing was evolved to suit contemporary faculty-academic nodes; the gozar to suit the leisure nodes, and the hayat explored with respect to its valid usage as a place of open space" (Mandala Collaborative \& Candilis, 1976, p. 15). Due to the topography of the hill, and in order to adapt to it, the main circulation spine varied in level and the floors were staggered. The result was an L-shaped building with the auditorium located at the turning point, which reached a height of up to seven floors even if the user experienced a maximum of three, was 100 meters wide and was dimensionally limited to 500 meters long, equivalent to 10 minutes' walk or "the time span allowed for in one class break" (see Figure 9). The classrooms and other facilities were arranged in this structured frame according to the curriculum subjects and the internal atmosphere was imagined as a kind of educational bazaar in which students enjoyed the wide corridors and meeting nodes (Figure 10).

ACE, 16 (4.7) CC BY-ND 3.0 ES | UPC Barcelona, España | Last Thoughts on Campus Planning by Georges Candilis: 


\section{ACE Architecture, City and Environment}

E-ISSN 1886-4805

Figure 9. BASU First campus design. Academic complex. Floor plan and section
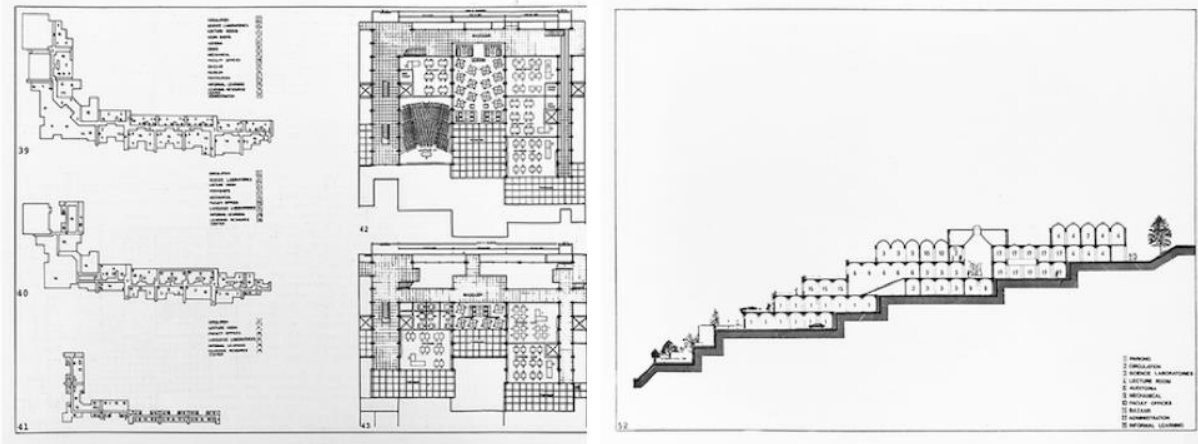

Source: IFA 322 01. Candilis Archives. Cité de l'architecture et du patrimoine.

Note: Master Plan BASU Report Three, March 1976

Figure 10. BASU First campus design. Academic complex. Interior perspectives
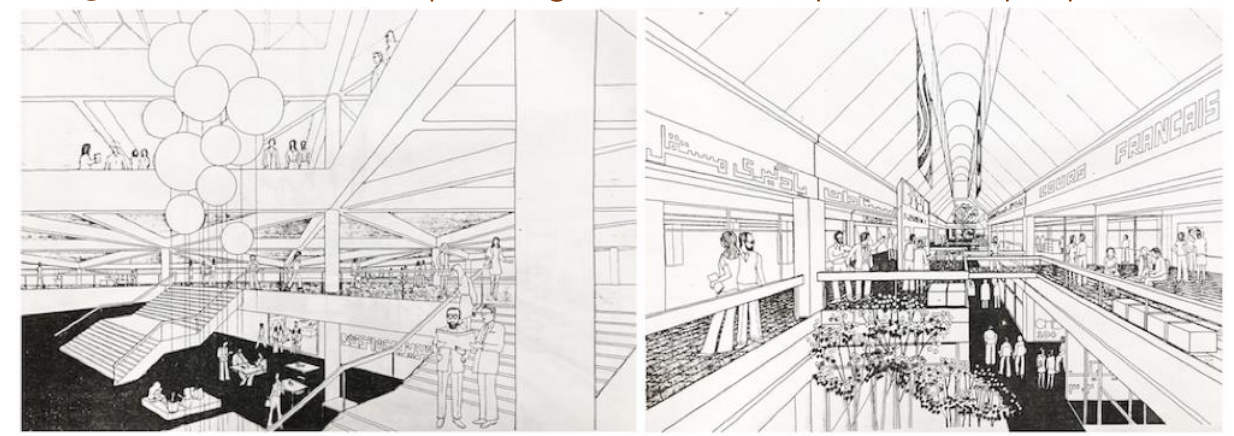

Source: IFA 322 01. Candilis Archives. Cité de l'architecture et du patrimoine.

The campus was completed with students housing and sports facilities. The student residence intended only for students in first-cycle - consisted of 25 type units, each housing 32 students, and layered in three levels (lounge area in the ground floor and upper floors for study and sleep). The conglomerate order is determined by a pattern of square pieces rotated 45 degrees that provide a zigzag circulation (Figure 11). The landscaping integrated the educational-administrative macrobuilding, the student housing and the sports facilities and the design took care of users according to the Iranian gardening tradition of water games: its function was to provide spaces for individual relaxation but also favouring the gathering for leisure activities. In addition to bringing together the three parts of the campus, the greenery design was also included in the interiors (for example, in the central spine of the academic building).

Figure 11. BASU First campus design. Student Housing.
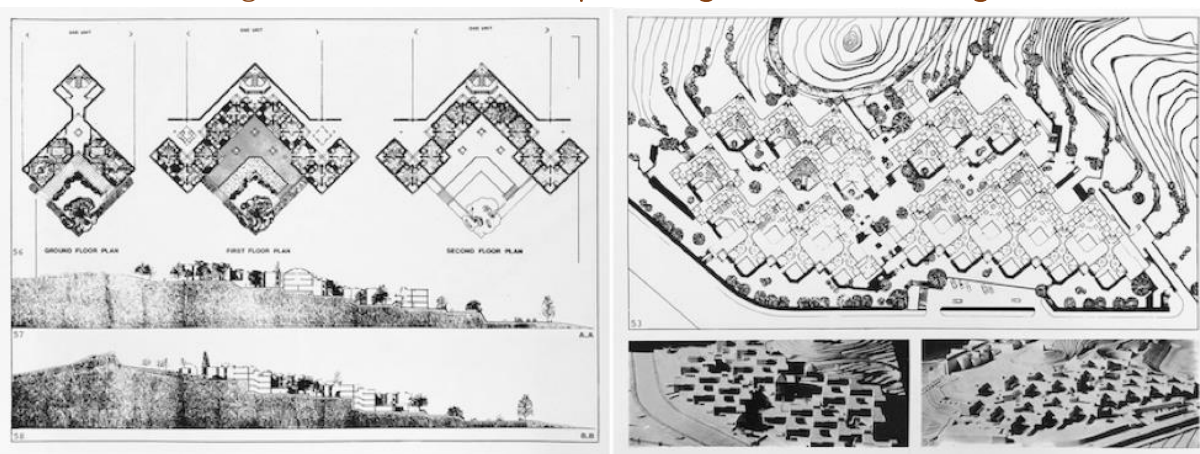

Source: IFA 322 01. Candilis Archives. Cité de l'architecture et du patrimoine. Note: Master Plan BASU Report Three, March 1976

ACE, 16 (47) CC BY-ND 3.0 ES | UPC Barcelona, España | Last Thoughts on Campus Planning by Georges Candilis: 


\section{Second Campus Planning and Buildings}

The 1976 Master Plan did not limit the university campus to its location on the hill. Indeed, some administrative services were planned into the historical city, in order to encourage the coming and going of people to the campus. Given the size of the BASU project, its construction was planned in three stages: the first phase of work involves academic buildings for 2,000 students (anticipated to be ready by September 1979), the second consists of additional academic buildings for 3,000 students as well as sport facilities, and the third phase, awaiting government decision, concerns the residential units.

This ambitious project, despite its detailed planning and design, will not be realized. Indeed, after almost three years of work, the BASU project on the hill was abandoned. According to Ardalan, the reason was essentially financial: "It cost so much to build on top of this hill because it was made entirely of stone ... that this idea [was] proved far too expensive and the site was relocated to somewhat distant in the area of ganjnameh" (Haeri, 1991, p. 42).

In fact, the architects were well aware of the financial cost of building on the hill from the beginning: in-depth studies on geology and soils had showed the necessity to respect the hill's natural slopes within the constructions in order to minimize the need of excavation by blasting (Mandala Collaborative \& Candilis, 1976). But as Candilis pointed out, the problem was that, within the "excessive economic euphoria" of these years, the Educational Ministry pursued the ideal of a technologically perfect work, for which would be hired the renowned American firm Skidmore Owings Merrill. "Technology crushed architecture" concluded Candilis: "As the final plans were developed, the original architectural idea gave way to a purely technological conception. A large number of specialists and technicians participated in this study according to American methods, in isolation, to solve each one's own problem ... without having a global vision of the work" (Candilis, 1978d, p. 3).

To shift this technological emphasis, a new site was chosen: a vast plain with rich vegetation and irrigation, located on the outskirts of the historical city. This site allowed to develop three premises, closer to Candilis' convictions: first, to maintain the existing orchards in order to respect the identity of the site; second, to conceive a plan in stages; and third, to relying on local technology without the support of any technical consultants. The chancellor of the university, Dr Farhad-e Ryahi, agreed to all these requirements (Haeri, 1991).

In 1977, a new and extensive campus was designed following a methodical approach. First, three functional areas were defined within the site: the faculty buildings area, a residential area for professors and staff, and a central area called Agora with communal service, and sports facilities (Figure 12). Second, the design efforts focused on the faculty area that should now be divided in several departments. Then, the architects proposed a neutral grid of two-level buildings, organized in square modules with a central courtyard (Figure 13).

This modular unit concept is inspired by the caravanserais and their aggregation system in the bazaars. The caravanserais are typical constructions of the Persian architecture whose function was the lodging of the travellers along the Silk Road. They were not just a place to rest and keep belongings safe after a day of travel; they also had a social and urban character since they were a meeting point for merchants, travellers, and scientists... The caravanserais' typologies are varied, but they mostly adopt rectangular or square shapes, closed to the outside and protected by a large access door, but open to a large central courtyard. Their composition is modulated through small vaulted rooms, arranged around the patio; when they have two floors, the social and commercial life is located on the ground level and the upper one is for rooms. These references are celebrated by Candilis in a short note, presenting in March 1978 the definitive project of the faculty area: "Considering that a

ACE, 16 (47) CC BY-ND 3.0 ES | UPC Barcelona, España | Last Thoughts on Campus Planning by Georges Candilis: 
university is not a 'monument' but a 'place', the architects have taken as a module the predominant urban element: the old caravanserai. Caravanserais are versatile two levels constructions (exchanges of ideas and products on the ground floor, dwellings upstairs). They are connected to each other through a network of lively alleys, with shops, mosques, schools, baths, etc. and other entertainments. All of this forms the bazaar. It's a university like this bazaar that we wanted to do. Each module of caravanserai corresponds to an educational department. At the crossroads of the links that connect four departments are placed their common services: auditoriums, clubs, library, administration offices, etc. ... each department can take a different form but the crossings and the links ensure the unity of the whole". (Candilis, 1978d, p. 3).

Figure 12. BASU Second campus design. General plan

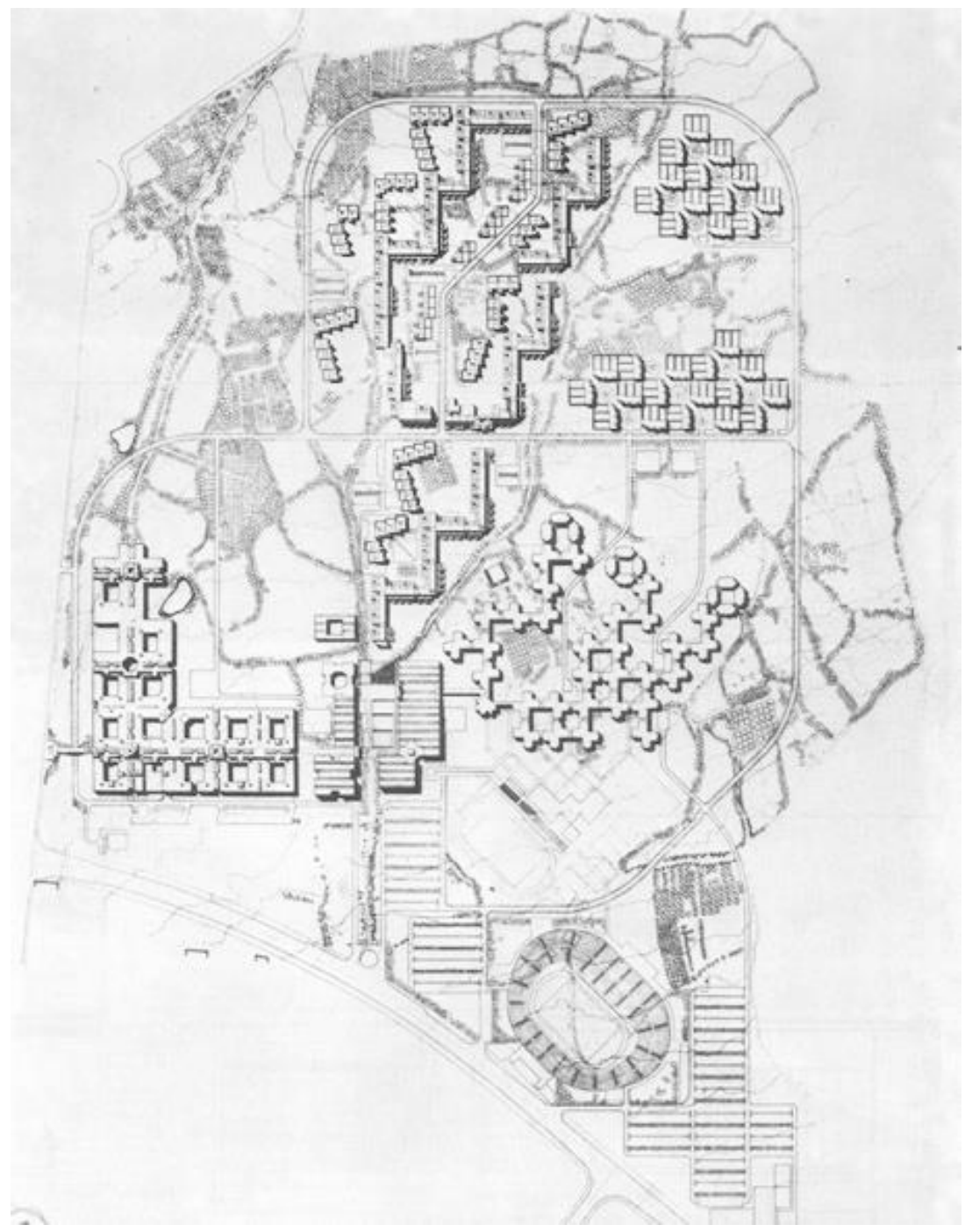

Source: Architecture d'Aujourd'hui (195).

Candilis' archives are testament to his attention to traditional Iranian architecture: his work folders include a compilation of references, as well as some photocopied images from the book The Sense of Unity (Ardalan \& Bakhtiar, 1973). Furthermore, Candilis' sketches show the testing of a serial and systematic design, which makes use of indigenous compositional elements from Persian architecture (Lüchinger, 1981) (Figure 14).

ACE, 16 (47) CC BY-ND 3.0 ES | UPC Barcelona, España | Last Thoughts on Campus Planning by Georges Candilis: 


\section{ACE Architecture, City and Environment}

E-ISSN $1886-4805$

These analyses guided the design of a first part of the academic area, made of four square-modules (Figure 15). The buildings of two levels have workspaces for great number on the ground floor (teaching) and for small groups upstairs (research). The intersections of the wings are magnified by a vaulted space, relating floor levels and lit by a striking dome. Available buildings resources were used for the technical development of the project: structural steel profiles, cast-in-place reinforced concrete slabs and brick enclosures.

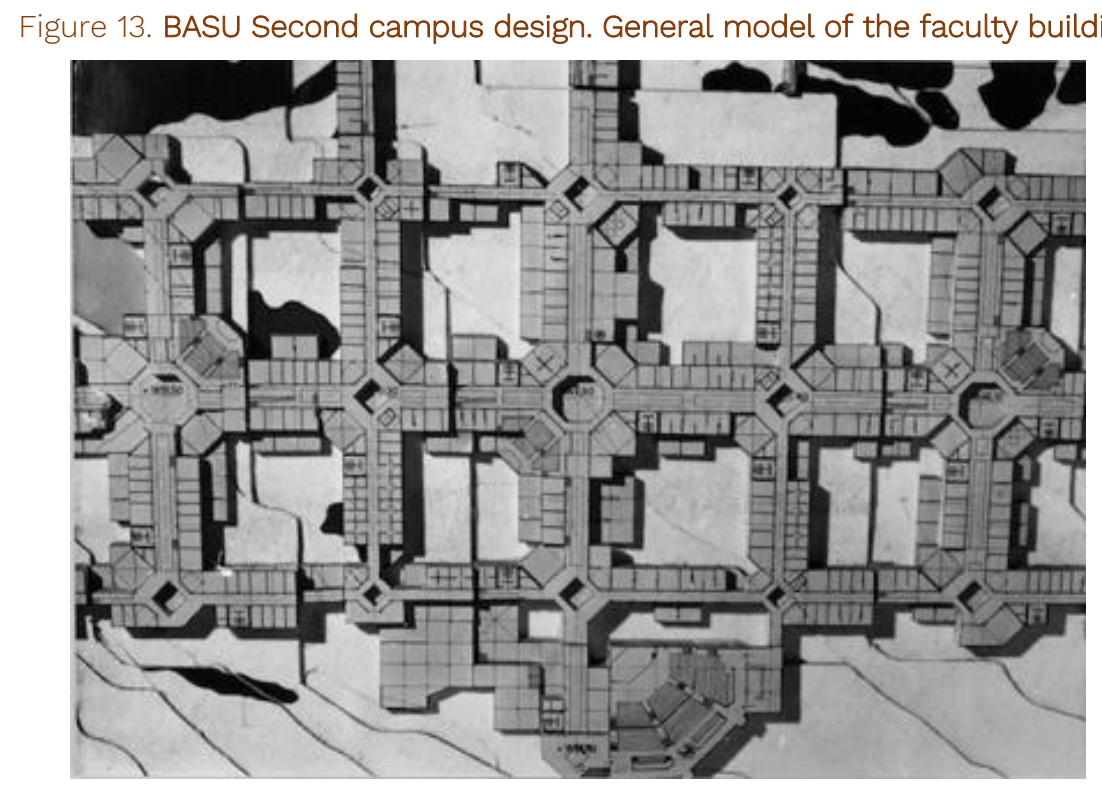

Source: IFA 322 01. Candilis Archives. Cité de l'architecture et du patrimoine.

Figure 14. BASU Second campus design. Sketches
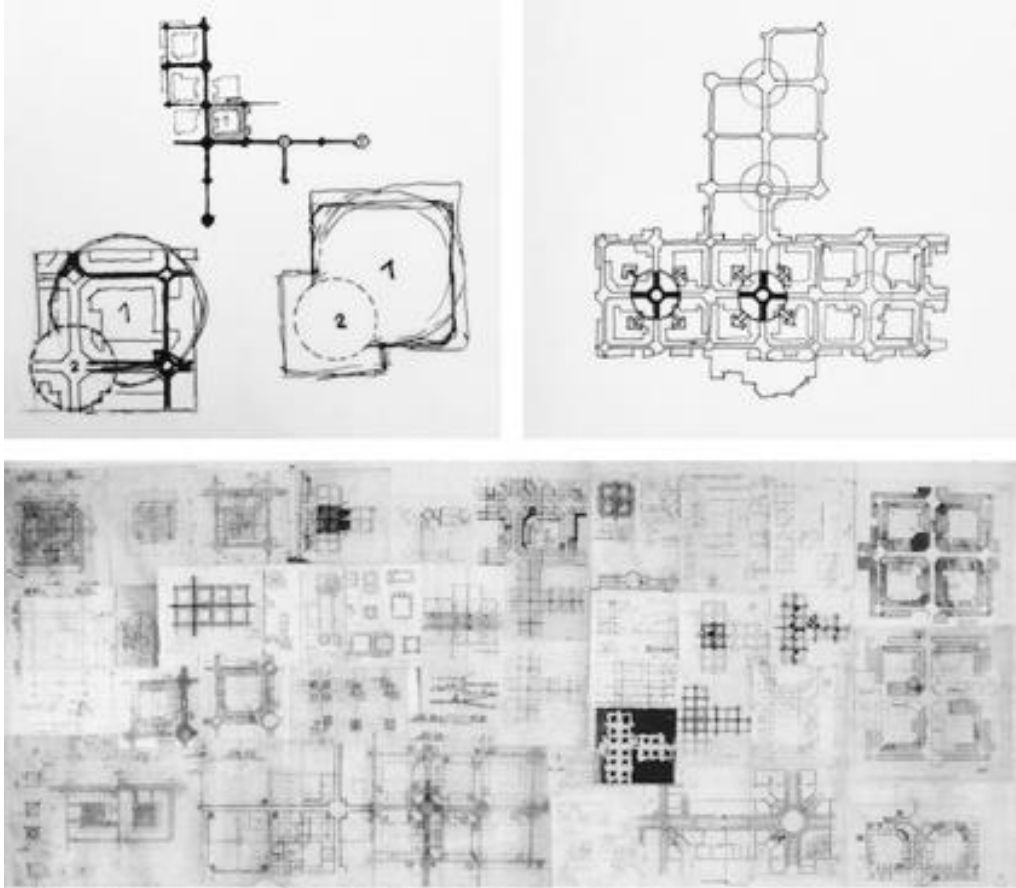

Source: Strukturalismus in Architektur und Städtebau, Lüchinger 1981; IFA 322 01. Candilis Archives. Cité de l'architecture et du patrimoine.

ACE, 16 (4.7) CC BY-ND 3.0 ES | UPC Barcelona, España | Last Thoughts on Campus Planning by Georges Candilis: 


\section{ACE Architecture, City and Environment}

Figure 15. BASU Second campus design. Section and model and of the built faculty units

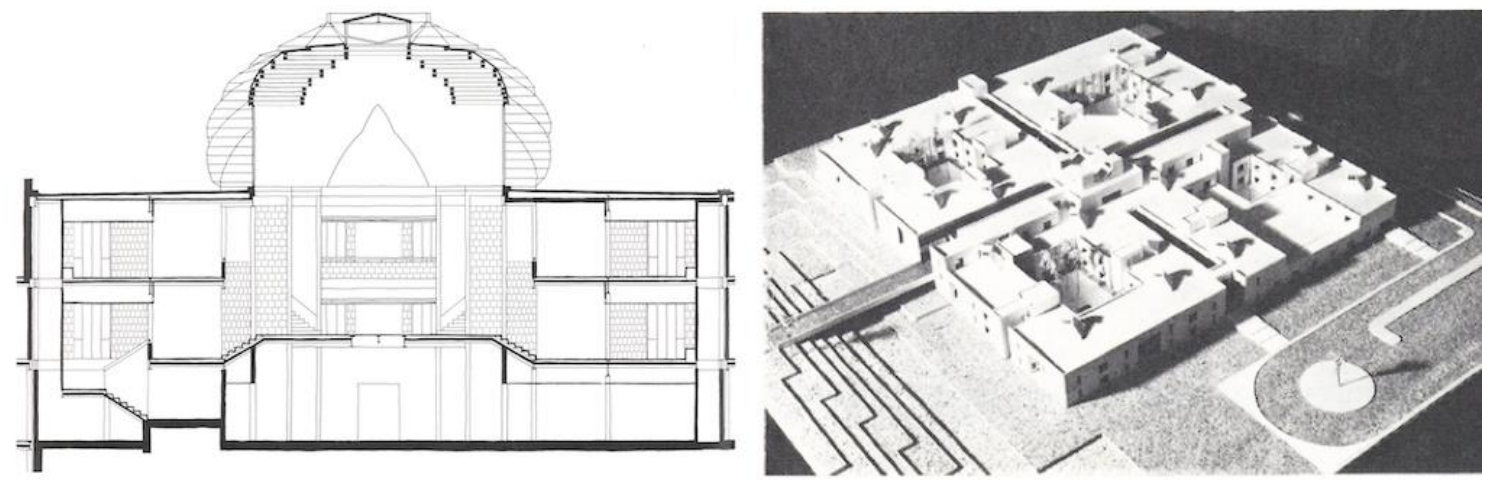

Source: Architecture d'Aujourd'hui (195).

\section{Conclusion}

In Iran, the period of rapid prosperity and accelerated modernization led by the unrelenting Shah Mohammad Reza Pahlavi ended in 1979, after months of popular protests that allowed the return of Rouhollah Khomeini (February 1st, 1979). The change of regime happened while the first BASU academic buildings were under construction. The architects did not supervise the work: they just received some photographs of the Faculty of Sciences modules: eight square sub-modules with courtyards, completed according to their plans (Haeri, 1991). This very first part, with its bright interiors, thanks to the linear skylights and the suspended corridors, bears the mark of collaboration between Candilis and Ardalan (Aghaei Rad, 2015). Nowadays, the BASU University, like many other universities, is a collection of constructions made over time, showing a variety of architectural writings.

The Mandala Collaborative firm in Tehran came to an end in 1979: from that moment on, Nader Ardalan based his practice in his Boston office. As for Georges Candilis, he pursued his career with planning commissions, in Greece as well as in the Middle East. However, with this last Faculty project, he completed a research process considering the requirements and determinants to the architectural design. In this sense, the functionalist conviction of the binomial analysis-proposal is relevant, and both the active institutional contributions (local government, deanery...) and the technicians' collaboration (geologists, engineers, pedagogues) play a significant role in pursuing social progress.

Regarding Candilis' career path of campus planning, a repetition of design strategies can be observed and are undoubtedly related to the way the program is understood and crafted. Revisiting the functionalist approach in light of structuralist thoughts about traditional architecture, Candilis separates the different functions, divides them into parts and subparts until obtaining elementary units, and then models them based on a determined organizational pattern that emphasizes relational spaces. If at the University of Bochum and in his solo proposal for the Université Libre de Bruxelles, the design strategy is understood as pieces linked to branches that are anchored to a central trunk ("stem" principle), at the Freie Universität Berlin, the proposal for the Dublin University College and the Faculté de la litérature of Toulouse-Le Mirail, the classrooms, seminars and offices come to nest in a warp (web principle). The university designs for Zurich, Madrid and Latakia might be understood as a kind of evolution of the web concept in which quadrangular modules with patios are arranged in bidirectional series. In this sense, the main building of the BASU first campus design is a linear organization similar to the stem concept, according to the space expressed in the perspectives of the corridors and the spatial configuration of the central spine, while the second campus design

ACE, 16 (47) CC BY-ND 3.0 ES | UPC Barcelona, España | Last Thoughts on Campus Planning by Georges Candilis: 
resembles the last explored models by means of a built grid with highlighted knots that act as compositional joints.

From the urban point of view, the university is organized in functional areas. In every project, the academic area is designed in an autonomous way, whereas the residential area, sports or leisure facilities have their own morphologies. Nevertheless, in all versions of the project, the Faculty buildings are laid out according to a continuous system, a common tapestry between faculties, departments, classrooms, offices, etc. Actually, the caravanserais' inspiration - which contains all the functions under the same shape - would have facilitated the arguments to go one step forward towards a total urban infrastructure.

In any case, the added value of BASU is a lesson learned in the relationships between cultural identities, the economy of resources, and commitment to the times. Ardalan and Candilis resorted to models of traditional Iranian architecture to shape a design that did not renounce modernity in its pedagogical approach and in its architectural proposal. It sought achievements in representative values from the institutional point of view and pursued the social benefit for the city all the while being built in a sustainable way, adopting the local techniques and resources for the good of the project.

\section{Acknowledgment}

This work was supported by the Universitat Politécnica de València under its Teaching Staff Career Development Programme (which enabled a research stay at the Centre National de Recherche Scientifique); and by the Spanish Ministry of Education, Culture and Sport under its Cooperation Scholarship for Students in University Departments (which enabled the student internships of Silvia Domene Camarasa).

\section{Author contributions}

The first author was responsible for the data gathering and consulted the drawing archives. Both authors conceived the study. The second author was in charge of historic contextualization. The first author wrote the first draft of the article and supervised the student internship for images processing. Both authors made final arrangements for the text.

Disclosure statement: No competing financial, professional, or personal interests from other parties are reported by the authors.

\section{Bibliography}

Aghaei Rad, H. (2015). A Study of the Architecture of Nader Ardalan in Terms of Tradition and Modernity in the Islamic Context. (Doctoral dissertation) University of New South Wales, Sydney. Retrieved from http://unsworks.unsw.edu.au/fapi/datastream/unsworks:39421/SOURCE02?view=true

Ardalan, N. \& Bakhtiar, L. (1973). The sense of unity: the Sufi tradition in Persian architecture. ABC International Group.

Blain, C. (2003). Team 10, The French Context. Paper presented in: Team 10, between Modernity and the Everyday (pp. 61-81). Delft, Netherlands. Retrieved from http://www.team10online.org

ACE, 16 (4.7) CC BY-ND 3.0 ES | UPC Barcelona, España | Last Thoughts on Campus Planning by Georges Candilis: Bu Ali Sina University (1973-1978). DOI: http://dx.doi.org/10.5821/ace.16.47.10455 
Bullock, N., Dickens, P. \& Steadman, P. (1970). Activities Space and Location. The Architectural Review, 147 (878), 299-308.

Candilis, G., Josic, A., \& Woods, S. (1964). Project for Bochum University. Architectural Design, 8(August), $376-377$.

Candilis, G. (1968). Universités Nouvelles: Toulouse. L'Architecture d'aujourd'hui, (137), 57-60.

Candilis, G. \& Mandala Collaborative. (1973). Université Bou Ali Sina. Hamadan Iran. Intermediary Report. [Fonds Candilis (236 Ifa 319/1). Archive d'architecture du XXe siècle, Paris, France].

Candilis, G. (1978a). Universidad Bu Ali Sina, Hamadan. L'Architecture d'Aujourd'hui, (195), 21-22.

Candilis, G. (1978b). Università Bou Ali Sina, Hamadan. Spazio e Società, 1(4), 17-28.

Candilis, G. (1978c). Università Bou Ali Sina, Hamadan. Deutsche Bauzeitung, (11), 16.

Candilis, G. (1978d). Université Bou Ali Sina Hamadan, Iran. [Fonds Candilis (236 Ifa 319/1). Archive d'architecture du XXe siècle, Paris, France].

Candilis, G. 1980. Bou Ali Sina University in Hamadan. Architecture in Greece, (14), 235-241.

Candilis, G. (2012). Bâtir la vie : un architecte témoin de son temps. Paris, France: Infolio.

Castellanos-Gómez, R., Domingo-Calabuig, D. \& Torres-Cueco, J. (2011). Los mat-buildings y las universidades de los 60. DPA, (27-28), 46-51. Retrieved from https://revista.dpa.upc.edu/ARCHIVO/DPA2728/dpa27.html

Chaljub, B. (2010). Candilis, Josic, Woods. Paris, France: Infolio, Éditions du Patrimoine.

Coulson, J., Roberts, P. \& Taylor, I. (2015). University planning and architecture: the search for perfection. Abingdon, Oxon, UK: Routledge.

De Carlo, G. (1968). Pianificazione e disegno delle università. Roma, Italy: Edizioni Universitarie Italiane.

Décret n 74-889 du 22 octobre 1974 portant publication de l'accord relatif à la création de l'université de Hamadan entre le Gouvernement de la République française et le Gouvernement impérial de l'Iran, signé à Téhéran le 26 février 1973. Journal Officiel de la République Française 26-10-1974, pp. 1092010 Retrieved from https://www.legifrance.gouv.fr

Domingo-Calabuig, D., Castellanos-Gómez, R. \& Torres-Cueco, J. (2012). El mat-building en las revistas de arquitectura españolas de los 60: la oportunidad de los nuevos campus universitarios. In Las revistas de arquitectura (1900-1975): crónicas, manifiestos, propaganda (pp.447-454). Pamplona, Spain: T6) Ediciones, D.L.

Emanuel, M. (1980). Contemporary Architects. London, UK: The Macmillan Press Ltd.

Haeri, S. (1991, July 21). Interview to Nader Ardalan. Foundation for Iranian Studies. Program of Oral History. Retrieved from https://fis-iran.org/en/content/ardalan-nader

Jockusch, P. \& Dunkl, W. (1974). University Campus Design. Architectural Design, 11(Nov.), 703-717.

ACE, 16 (47) CC BY-ND 3.0 ES | UPC Barcelona, España | Last Thoughts on Campus Planning by Georges Candilis: 
Joedicke, J. (1978). Candilis-Josic-Woods: una década de arquitectura y urbanismo. Barcelona, Spain: Editorial Gustavo Gili, S.A.

Lüchinger, A. (1981). Strukturalismus in Architektur und Städtebau. Stuttgart, Germany: Krämer.

Mandala Collaborative \& Candilis, G. (1973). Bou Ali Sina University. Master Plan Report One. [Fonds Candilis (236 Ifa 319/1). Archive d'architecture du XXe siècle, Paris, France].

Mandala Collaborative \& Candilis, G. (1974). University Residence Analysis. Bou Ali Sina University. [Fonds Candilis (236 Ifa 319/1). Archive d'architecture du XXe siècle, Paris, France].

Mandala Collaborative \& Candilis, G. (1976). Bu Ali Sina University. The Master Plan Report Phase Three for a University in Hamadan, Iran. [Fonds Candilis (236 Ifa 319/1). Archive d'architecture du XXe siècle, Paris, France].

Muthesius, S. (2000). The Postwar University. Utopianist Campus and College. New Haven, USA: Yale University Press.

Pedret, A. (2013). Team 10: An Archival History. Abingdon, Oxon, UK: Routledge.

Risselada, M. \& Heuvel, D. van den. (2005). Team 10. 1953-81. in search of a Utopia of the present. Rotterdam, Netherlands: NAi Publishers.

SCET-COOP (n.d.), Kuwait University. [Fonds Candilis (236 Ifa 319/1). Archive d'architecture du XXe siècle, Paris, France].

Sennott, R. S. (2004). Encyclopedia of Twentieth Century Architecture. New York: Taylor \& Francis Books.

Smithson, A. (1974). How to recognise and read mat-building. Architectural Design, 9(Sept.), 573-590.

Tehranian, M. (1993). Islamic Fundamentalism in Iran and the Discourse of Development. In Marty, M.E. \& Appleby, R.S. (Eds.), Fundamentalisms and Society: Reclaiming the Sciences, the Family, and Education (pp. 341-373). Chicago, USA: University of Chicago Press.

ACE, 16 (4.7) CC BY-ND 3.0 ES | UPC Barcelona, España | Last Thoughts on Campus Planning by Georges Candilis: 